\title{
Aerobic and anaerobic metabolism of a sediment enriched with Spartina detritus
}

\author{
Paul E. Kepkay and Frede Ø. Andersen* \\ Marine Ecology Laboratory, Bedford Institule of Oceanography, P.O. Box 1006, Dartmouth, N.S. B2Y 4A2, Canada
}

\begin{abstract}
Metabolism of a salt-marsh sediment, kept flooded at constant temperature, was monitored for $30 \mathrm{~d}$ after burial of fresh and aged Spartina detritus. Carbon dioxide released by the sediment was between 2.0 and 6.9 times the oxygen taken up, indicating that the anaerobic mineralization of organic carbon was predominant. Sulfate reduction accounted for only $21 \%$ of the $\mathrm{CO}_{2}$ production during an initial $8 \mathrm{~d}$ period of rapid decomposition, but became more dominant as decomposition slowed, eventually accounting for $77 \%$ of the $\mathrm{CO}_{2}$ produced. Selective inhibition of sulfate reduction and total respiration demonstrated that the production of dissolved organic carbon (DOC) and its mineralization within the sediment were closely associated. As a result, very little of the DOC escaped into the water column. Instead, it fuelled an active anaerobic community, expressed in terms of the large production and upward flux of $\mathrm{CO}_{2}$
\end{abstract}

\section{INTRODUCTION}

Recent studies have shown that the marsh grass Spartina alterniflora Loisel is an important source of organic carbon in the Bay of Fundy. Gordon et al. (1984) calculated an average low-marsh primary production of $272 \mathrm{~g} \mathrm{C} \mathrm{m}^{-2} \mathrm{yr}^{-1}$, which is $29 \%$ of the total primary production in the bay. Stable carbon isotope analyses (Schwinghamer et al., 1983) suggested that some of the Spartina may reach higher trophic levels even though the marshes are not subject to extensive grazing by herbivores (Mann, 1972; Patriquin, 1981). Most of the Spartina production becomes detritus which is either buried in marsh sediments or transported by tidal currents to other environments (Roberts, 1982; Hargrave et al., 1983; Schwinghamer et al., 1983; Gordon et al., 1984).

The decomposition of Spartina has been examined primarily as an above-ground process, with the plant detritus contained in litter bags on or above the sediment surface (e.g. Odum and de la Cruz, 1967; Marinucci, 1982). However, a substantial component of the plant's biomass is subject to decomposition within sediments. The below-ground production of Spartina roots usually exceeds the production above ground

\footnotetext{
- Present address: Institute of Biology, Odense University, Campusvej 55, DK-5230 Odense M., Denmark
}

(Good et al., 1982), and the burial of detritus would add to this source of decomposable material. The decomposition rates of buried material range from 0 to $80 \%$ weight loss in $1 \mathrm{yr}$ when detritus is placed at $20 \mathrm{~cm}$ below the sediment surface (Howarth and Hobbie, 1982). This wide range of values is presumably related to variation in the degree of anoxia between sediments and to the use of either living or dead material in the experiments.

Andersen and Hargrave (1984) found that the decomposition of fresh, above-ground Spartina placed in an intertidal sediment resulted in an $84 \%$ reduction of the original particulate fraction over $105 \mathrm{~d}$. Approximately $67 \%$ of this loss could be attributed to mineralization of the carbon, with aerobic processes accounting for $21 \%$ of the $\mathrm{CO}_{2}$ produced and anaerobic processes, such as sulfate reduction (Howarth and Hobbie, 1982), accounting for the remaining $79 \%$. Only $2.8 \%$ of the detritus escaped from the sediment as dissolved organic carbon (DOC) over the same time period. These low release rates could have been due to low production within the sediment or high production coupled to high consumption, so that the DOC was mineralized before it could be released. The second contention is indirectly supported by the results from Andersen and Hargrave's (1984) aerobic leaching experiments, which indicate that up to $51 \%$ of the detritus could be mobilized as DOC in only a few days. 
Valiela et al. (cited in Howarth and Hobbie, 1982) also found that this type of leaching produced a similar (20 to $50 \%$ ) loss of weight over a period of $1 \mathrm{wk}$.

We report here the results from experiments designed to determine if the rapid production of DOC from buried detritus is directly associated with an equally rapid consumption by aerobic and anaerobic mineralization. The experiments were carried out in aquaria containing sediment and different types of Spartina detritus from an intertidal area of the Bay of Fundy. Sulfate reduction was also selectively inhibited to determine the effect of this process on $\mathrm{CO}_{2}$ and DOC release from the sediment.

\section{MATERIALS AND METHODS}

Detritus and sediment preparation. Intertidal, low marsh sediment was collected from a site near Grand Pré in the Minas Basin. The general characteristics of the sediment and the production of Spartina alterniflora at this site in the upper reaches of the Bay of Fundy have been described by Mackinnon and Walker (1979) and Smith et al. (1980). Aerobic sediment was collected as a $3 \mathrm{~cm}$ thick layer and forced, rather than washed, through a $1 \mathrm{~mm}$ sieve to maintain the natural porosity. This type of sieving removed most of the macrofauna, leaving the meio- and microfauna intact. In the laboratory, 4 aquaria $(35 \mathrm{~cm}$ long, $20 \mathrm{~cm}$ wide, $20 \mathrm{~cm}$ deep) were filled with the sediment to a depth of $6 \mathrm{~cm}$. Fresh seawater at a temperature of $10^{\circ} \mathrm{C} \pm 1 \mathrm{C}^{\circ}$ was allowed to fill each aquarium and slowly flow over the sediment surface. The aquaria were left for $2 \mathrm{~d}$ to allow suspended material to settle out and the sediment temperature to equilibrate with the seawater. After this equilibration period, water was drained from each aquarium so that Spartina detritus could be spread on the sediment surface.

Two different types of detritus were prepared, one of which was fresh or new growth harvested in late July 1982 by Andersen and Hargrave (1984). The second type of detritus was weathered or aged material collected from the Grand Pré site in April 1983 and which remained from the previous growing season. The plant material was rinsed in cold tap water, cut into $1 \mathrm{~cm}$ pieces and dried at $60^{\circ} \mathrm{C}$ for $1 \mathrm{~d}$. The dry material was ground in a blender, sieved through a $0.85 \mathrm{~mm}$ mesh and the fine fraction dried at $60^{\circ} \mathrm{C}$ to constant weight. In 3 of the aquaria, finely-ground detritus was evenly distributed on each sediment surface to a thickness of $0.5 \mathrm{~cm}$. In the remaining aquarium, detritus was not added. Of the 3 aquaria with added detritus, 1 contained $50 \mathrm{~g}$ of fresh material $\left(714 \mathrm{~g} \mathrm{~m}^{-2}\right), 1$ contained $50 \mathrm{~g}$ of aged material $\left(714 \mathrm{~g} \mathrm{~m}^{-2}\right)$ and 1 contained $14 \mathrm{~g}$ of aged material $\left(200 \mathrm{~g} \mathrm{~m}^{-2}\right)$. The fine grain size of the detritus was required in our experiments to ensure that the material was distributed uniformly in each aquarium. This allowed the results from different aquaria to be directly compared, but also meant that our detritus was not representative of larger, natural detrital particles.

Approximately $750 \mathrm{ml}$ of sieved sediment were added to each aquarium, forming a layer that was $1 \mathrm{~cm}$ thick on top of the detritus in 3 aquaria and a $1.5 \mathrm{~cm}$ thick layer in the aquarium without detritus. The aquaria were reflooded and left for the duration of a $30 \mathrm{~d}$ experiment with a seawater inflow of approximately $40 \mathrm{ml} \mathrm{min}{ }^{-1}$ at $10^{\circ} \mathrm{C} \pm 1 \mathrm{C}^{\circ}$. Throughout the experiment sediment Eh was monitored; the techniques used to measure and calculate the redox potentials are described by Hargrave (1972).

Flux of $\mathrm{O}_{2}, \mathrm{CO}_{2}$ and DOC. Duplicate cores $15.7 \mathrm{~cm}$ in diameter and $11.5 \mathrm{~cm}$ in length) were placed in each aquarium to determine the flux of $\mathrm{O}_{2}, \mathrm{CO}_{2}$ and DOC across the sediment surface. A detailed description of the methods used here appears in Andersen and Hargrave (1984). Seawater was siphoned out of the aquaria to expose the water column in each core for oxygen measurements and to collect water for $\mathrm{CO}_{2}$ and $\mathrm{DOC}$ analysis. The top of each core was sealed with a plexiglass lid so that there was no head space of air and a rotating magnetic stir bar on the underside of the lid gently mixed the water above the sediment surface. The aquaria were refilled to cover the sealed cores and maintain constant temperature during a dark incubation period. The inflow of fresh seawater over the open cores between incubations ensured that the water above each sediment surface remained saturated with oxygen and incubation times ( 2 to $4 \mathrm{~h}$ ) were chosen so that dissolved oxygen above the sediment did not decrease by more than $10 \%$. This ensured that oxygen did not limit the activities of organisms at the sediment surface during incubations and between incubations. At the end of each incubation, water was again drained from each aquarium to expose the tops of the sealed cores. In order to minimize contamination of the water by gas exchange with the atmosphere, oxygen was measured and water samples were collected for $\mathrm{CO}_{2}$ and DOC analysis as soon as the plexiglass lid was removed from each core. Fluxes were calculated as the difference between measurements taken at the beginning and end of each incubation period. Dissolved oxygen measurements were carried out with an electrode (Yellow Springs Instruments, Model 54A) and were precise to $\pm 0.1 \mathrm{mg} \mathrm{O} \mathrm{O}^{-1}$. Total dissolved carbon dioxide was determined by gas-stripping $20 \mathrm{ml}$ samples of water in $50 \mathrm{ml}$ glass syringes and analyzing the gases evolved for $\mathrm{CO}_{2}$ on a gas chromatograph (Stainton, 1973). At the beginning of the incubations, seawater samples were taken outside the cores and at 
the end of the incubations, samples were taken inside the cores. Duplicate $8 \mathrm{ml}$ aliquots were taken for DOC analysis and filtered through $0.2 \mu \mathrm{m}$ membranes (Millipore). The filtered samples were stored frozen in glass tubes that had been precombusted to $550^{\circ} \mathrm{C}$ and were analyzed using the UV oxidation technique of Gershey et al. (1979). A small core was taken from the aquarium containing fresh detritus at the end of the experiments for the analysis of total organic carbon. Slices of sediment $0.5 \mathrm{~cm}$ in thickness were acidified with $1 \mathrm{~N} \mathrm{HCl}$, dried at $60^{\circ} \mathrm{C}$ to remove carbonates and analyzed for organic carbon on a Perkin-Elmer 240 elemental analyzer. Sub-samples of the fresh and aged Spartina added to the aquaria were also acidified and dried for organic carbon analysis.

Flux of ${ }^{14} \mathrm{CO}_{2}$ and $\mathrm{DO}^{14} \mathrm{C}$. Three additional cores $(2.5 \mathrm{~cm}$ in diameter, $11.5 \mathrm{~cm}$ in length) were placed in the sediment with fresh detritus to determine the effect of selected metabolic inhibitors on the flux of $\mathrm{CO}_{2}$ and DOC between water and sediment. ${ }^{14} \mathrm{C}$ labelled hay, with a specific activity of $0.04 \mu \mathrm{Ci} \mathrm{mg}^{-1}$ dry weight, was mixed with a small amount of sieved sediment. The hay and wet sediment were immediately taken up into a syringe and $0.2 \mathrm{ml}$ of the slurry (containing $15.8 \pm 1.0 \mathrm{mg}$ of dry hay or $1.422 \times 10^{6} \pm$ $8.7 \times 10^{4} \mathrm{dpm}$ ) were injected $1.5 \mathrm{~cm}$ below the sediment surface. Three aliquots of the slurry were also injected into small glass beakers, freeze-dried for $24 \mathrm{~h}$ and analyzed for their $\mathrm{PO}^{14} \mathrm{C}$ content by combustion of each aliquot in a sample oxidizer to release the labelled POC as ${ }^{14} \mathrm{CO}_{2}$. This $\mathrm{CO}_{2}$ was trapped in $5 \mathrm{ml}$ of ethanolamine/2-ethoxyethanol $(1: 7)$ and counted in a scintillation counter (Searle, Mark III) after the addition of $10 \mathrm{ml}$ of fluor (Lipoluma). In one core, $1 \mathrm{ml}$ of $20 \mathrm{mM}$ sodium molybdate was injected at $1.5 \mathrm{~cm}$ to inhibit sulfate reduction (Oremland and Taylor, 1978; Sørensen et al., 1981) and $20 \mathrm{ml}$ of $20 \mathrm{mM}$ sodium molybdate in seawater were added above the sediment surface. In another core, $1 \mathrm{ml}$ of $20 \mathrm{mM}$ sodium azide was injected at the same horizon and added above the sediment to inhibit the respiration of oxygen and nitrate (Stouthamer et al., 1980) as well as sulfate reduction (Thauer and Badziong, 1980). The third core contained no inhibitor and only seawater was added above the sediment. The $20 \mathrm{ml}$ water column in each core was closed at the top, leaving a $3 \mathrm{ml}$ head space of air, and was gently bubbled with air to both oxygenate and mix the water without disturbing the sediment. The outlet from each head space was bubbled through a scintillation vial and Vigereaux tube which contained $5 \mathrm{ml}$ of Oxifluor (New England Nuclear) to remove the ${ }^{14} \mathrm{CO}_{2}$ stripped from the water column.

The ${ }^{14} \mathrm{CO}_{2}$ and $\mathrm{DO}^{14} \mathrm{C}$ released into each water column were measured over 2 time intervals, 0 to $8 \mathrm{~d}$ and 20 to $28 \mathrm{~d}$. The Oxifluor in each of the $\mathrm{CO}_{2}$ traps was removed each day and counted directly on a liquid scintillation counter (Beckman, model LS3133T). While the traps were being replenished with fresh Oxifluor, a $2 \mathrm{ml}$ sample from each water column was acidified in a closed $30 \mathrm{ml}$ serum bottle with $0.2 \mathrm{ml}$ of $2 \mathrm{~N} \mathrm{H}_{2} \mathrm{SO}_{4}$ to remove the ${ }^{14} \mathrm{CO}_{2}$ which was not stripped by bubbling. This $\mathrm{CO}_{2}$ was collected on filter paper wicks soaked in $0.2 \mathrm{ml}$ of $\beta$ phenethylamine (Griffiths et al., 1977; Novitsky and Kepkay, 1981) and the wicks were counted by liquid scintillation in $5 \mathrm{ml}$ of Aquasol (New England Nuclear). The acidified seawater remaining in the serum bottle was filtered through a $0.2 \mu \mathrm{m}$ membrane (Millipore) and counted as the $\mathrm{DO}^{14} \mathrm{C}$ fraction in $5 \mathrm{ml}$ of Aquasol (New England $\mathrm{Nu}$ clear). The water column in each core was replenished with $2 \mathrm{ml}$ of seawater, $2 \mathrm{ml}$ of $20 \mathrm{mM}$ molybdate and $2 \mathrm{ml}$ of $20 \mathrm{mM}$ azide respectively before bubbling was resumed so that the water columns were kept at con-
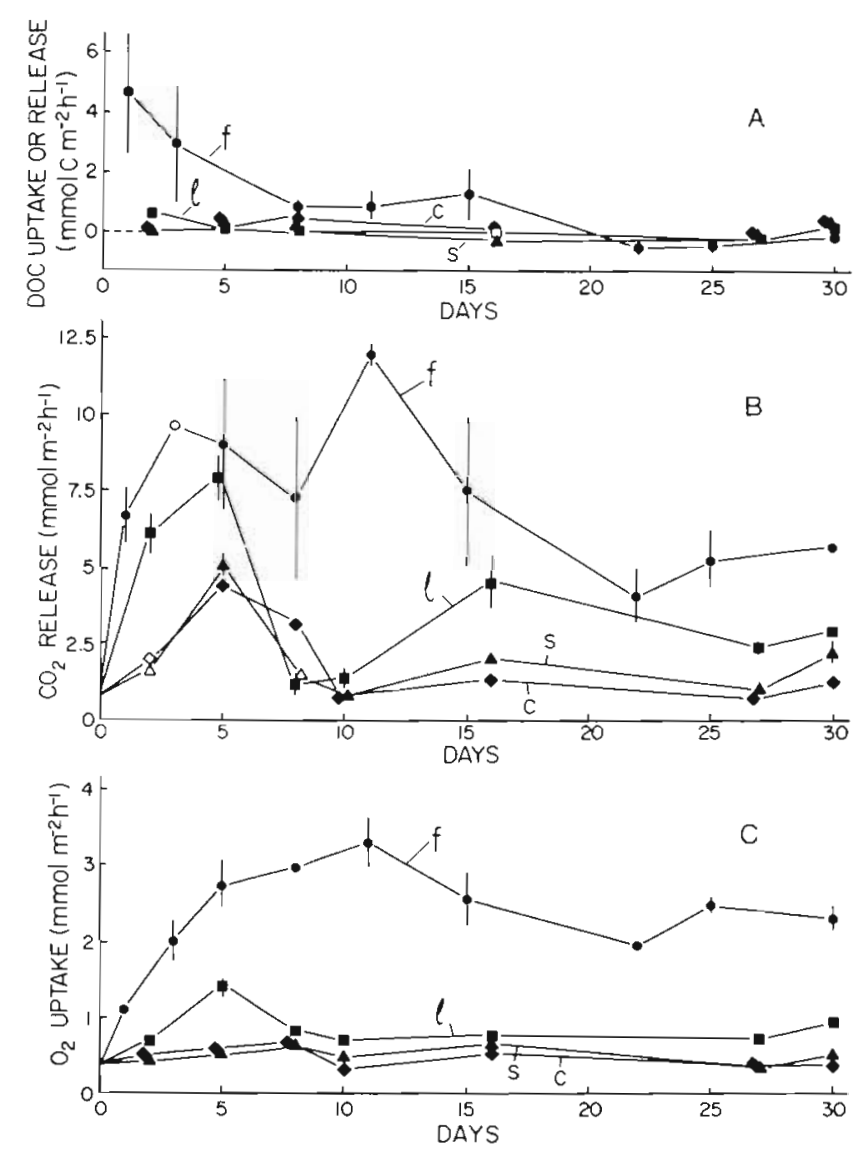

Fig. 1. (A) Dissolved organic carbon release rate (positive values) or uptake rate (negative values); (B) carbon dioxide release rate; (C) rate of oxygen uptake by sediment kept at constant temperature. Four different sediments were examined, containing $50 \mathrm{~g}$ of fresh detritus (f), $50 \mathrm{~g}$ of aged detritus (l), $14 \mathrm{~g}$ of aged detritus (s) and no added detritus (c). Error bars: range of duplicate measurements, except in cases where the range was smaller than the closed symbols; open symbols: single measurements 

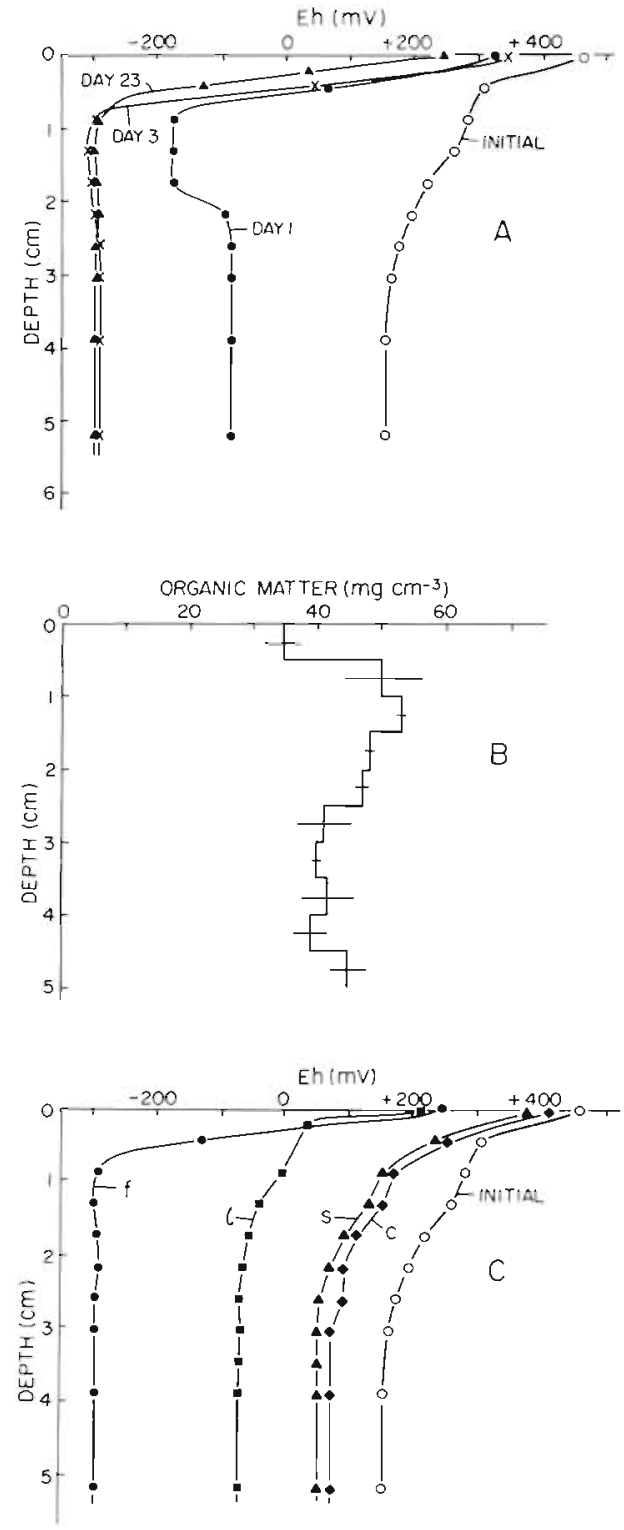

Fig. 2. (A) Redox potentials measured after burial of fresh detritus for 1,3 or $23 \mathrm{~d}_{\text {; }}$ (B) organic material profile of the sediment containing fresh detritus after $30 \mathrm{~d}$ decomposition; (C) redox potentials in the sediments containing $50 \mathrm{~g}$ of fresh detritus (f), $50 \mathrm{~g}$ of aged detritus (1), $14 \mathrm{~g}$ of aged detritus (s) and no detritus (c) after $30 \mathrm{~d}$ decomposition

stant volume. Thus dilution corrections had to be applied to subsequent samples.

When the experiments were terminated at $28 \mathrm{~d}$, the 3 cores were removed from the aquarium and immediately frozen in liquid nitrogen. The sediment in each core was cut into $0.5 \mathrm{~cm}$ slices and acidified with $1 \mathrm{ml}$ of $0.2 \mathrm{~N} \mathrm{H}_{2} \mathrm{SO}_{4}$ in sealed test tubes. The ${ }^{14} \mathrm{CO}_{2}$ evolved was collected on filter paper wicks soaked in $0.2 \mathrm{ml}$ of $\beta$ phenethylamine and the wicks counted as before. Each slurry of acidified sediment was centrifuged at
$27,000 \times \mathrm{g}$ for $15 \mathrm{~min}$ at $20^{\circ} \mathrm{C}$. The supernatant was removed, filtered through a $0.22 \mu \mathrm{m}$ membrane (Millipore) and counted as the $\mathrm{DO}^{14} \mathrm{C}$ fraction after correction for sediment porosity and dilution by the acid. The acidification of sediment with $0.2 \mathrm{~N} \mathrm{H}_{2} \mathrm{SO}_{4}$ does not convert $\mathrm{PO}^{14} \mathrm{C}$ to $\mathrm{DO}^{14} \mathrm{C}$ (Novitsky and Kepkay, 1981), but higher concentrations of the acid can cause a small fraction (less than $2 \%$ ) of the POC to solubilize. The particulates remaining after acidification were freeze dried for $24 \mathrm{~h}$ and analyzed for $\mathrm{PO}^{14} \mathrm{C}$ on the sample oxidizer.

\section{RESULTS}

The rate of carbon dioxide release by the sediments increased rapidly in all of the aquaria during the first $5 \mathrm{~d}$, decreased from 5 to $8 \mathrm{~d}$ and increased again from
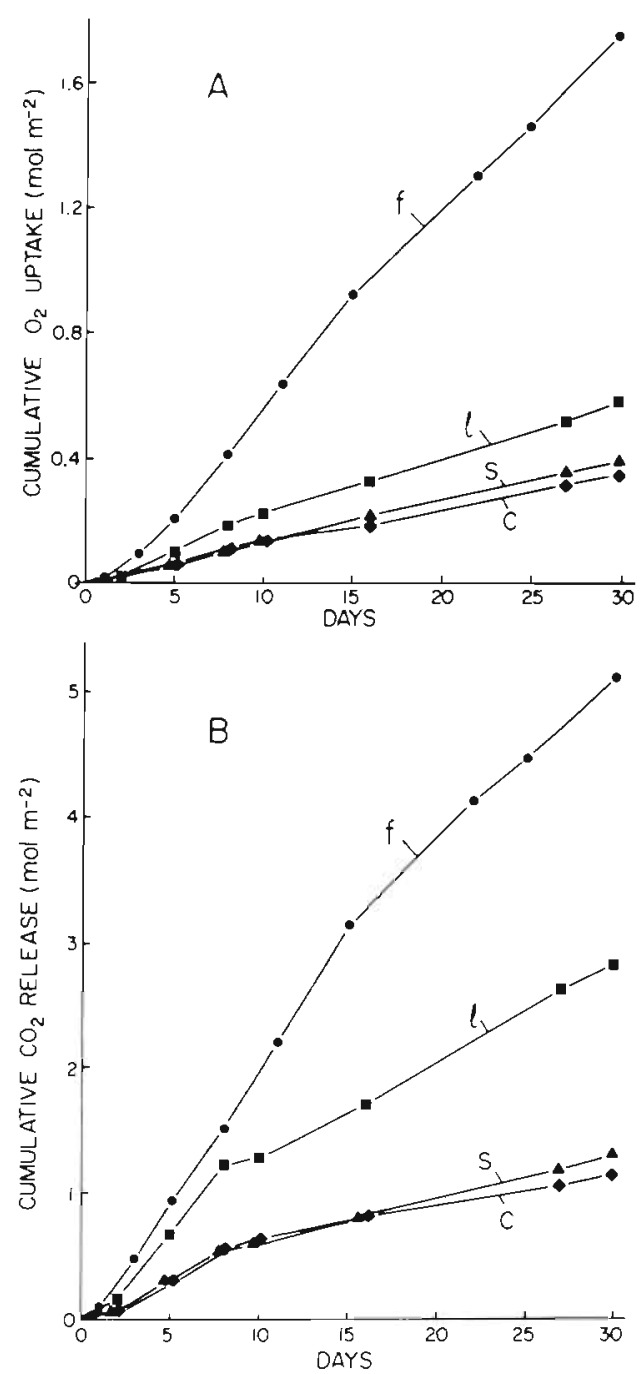

Fig. 3. Cumulative oxygen uptake and carbon dioxide release by sediment containing fresh (f), aged ( 1 and s) or no detritus (c) 


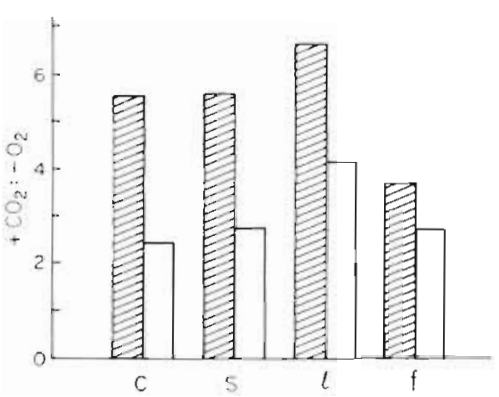

Fig. 4. Ratio between carbon dioxide released $\left(+\mathrm{CO}_{2}\right)$ and oxygen taken up $\left(-\mathrm{O}_{2}\right)$ by sediment containing fresh (f), aged (l and s) or no detritus (c). Shaded columns: cumulative ratios for 0 to $8 \mathrm{~d}$; open columns: equivalent ratios for 8 to $30 \mathrm{~d}$

8 or 10 to $15 \mathrm{~d}$ (Fig. 1B). All of these variations in $\mathrm{CO}_{2}$ release rate occurred despite the maintenance of constant temperature in the aquaria. During the same period of time, the oxygen uptake rate (Fig. 1C) increased in the aquaria containing $50 \mathrm{~g}$ of fresh or aged detritus during the first $5 \mathrm{~d}$. The uptake rate continued to rise from 5 to $10 \mathrm{~d}$ in the aquarium containing fresh detritus and decreased after $10 \mathrm{~d}$. In the aquarium containing $50 \mathrm{~g}$ of aged detritus, the uptake rate decreased from 5 to $10 \mathrm{~d}$ and remained uniform after $10 \mathrm{~d}$. The uptake rates in the aquaria containing $14 \mathrm{~g}$ of aged detritus or no detritus remained essentially constant at low values during the entire experiment. The DOC release rate either decreased or remained near zero during the experiment (Fig. 1A), and often reached slightly negative values, indicating a small amount of DOC uptake rather than release. Oxygen uptake and $\mathrm{CO}_{2}$ release rates by sediment containing $50 \mathrm{~g}$ of fresh or aged detritus tended to be
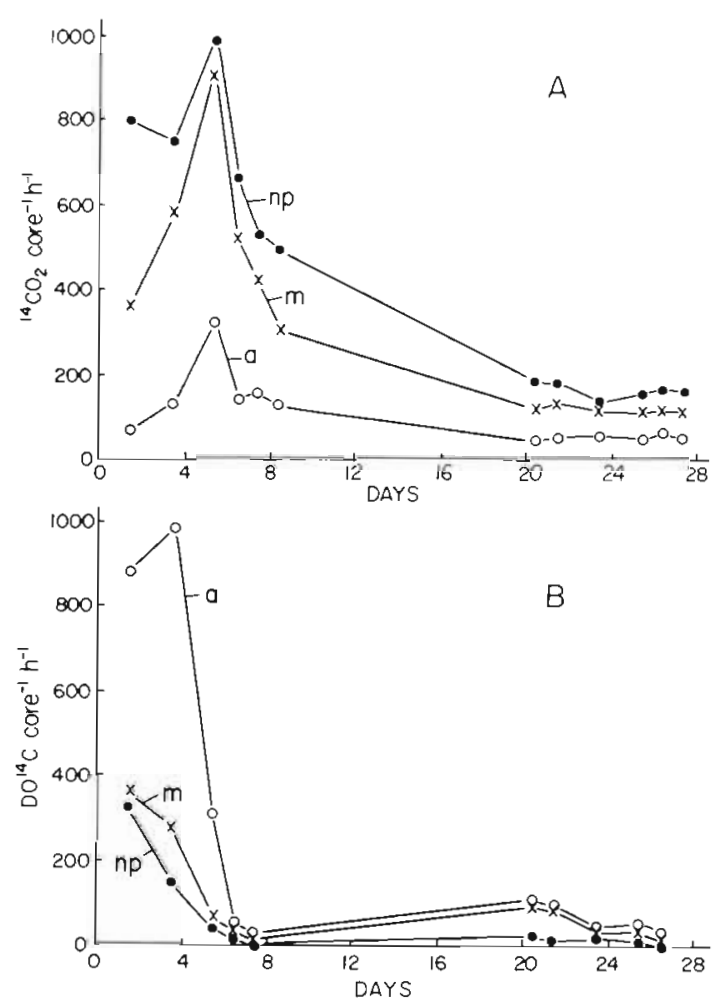

Fig. 5. (A) ${ }^{14} \mathrm{CO}_{2}$ release rates; (B) $\mathrm{DO}^{14} \mathrm{C}$ release rates from sediment containing fresh detritus in cores that were not inhibited (np), molybdate inhibited (m), or azide inhibited (a)

greater than rates from the same sediment containing $14 \mathrm{~g}$ of aged material or no added detritus. Carbon dioxide release was between 2 and 6 times the $\mathrm{O}_{2}$ uptake, and appeared to be dependent on the amount of detritus added (Fig. 1B). Turnover of organic carbon

Table 1. Organic carbon turnover of aged and fresh detritus during $30 \mathrm{~d}$ of decomposition. The amount of detritus mineralized from 0 to $30 \mathrm{~d}$ has been calculated from the cumulative oxygen uptake and carbon dioxide release in Fig. 3

\begin{tabular}{|c|c|c|c|c|c|c|c|}
\hline \multirow{2}{*}{$\begin{array}{l}\text { Type of } \\
\text { detritus }\end{array}$} & \multirow{2}{*}{$\begin{array}{c}\text { Detritus } \\
\text { added }^{\mathrm{a}} \\
\text { (mgC core }^{-1} \text { ) }\end{array}$} & \multicolumn{3}{|c|}{$\mathrm{O}_{2}$ uptake } & \multicolumn{3}{|c|}{$\mathrm{CO}_{2}$ release } \\
\hline & & $\begin{array}{c}\mathrm{O}_{2} \\
\text { uptake } \\
\left.\text { (mmol core }{ }^{-1}\right)\end{array}$ & $\begin{array}{c}C \text { mineral- } \\
\text { ized } \\
\left(\mathrm{mg} \mathrm{C}^{\mathrm{C}} \text { core }^{-1}\right)\end{array}$ & $\begin{array}{l}\% \text { detritus } \\
\text { mineralized }\end{array}$ & $\begin{array}{c}\mathrm{CO}_{2} \\
\text { production } \\
\left(\mathrm{mmol} \text { core }^{-1}\right)\end{array}$ & $\begin{array}{c}\mathrm{C} \text { mineral- } \\
\text { ized }^{\mathrm{c}} \\
\left(\mathrm{mg} \mathrm{C} \text { core }^{-1} \text { ) }\right.\end{array}$ & $\begin{array}{l}\% \text { detritus } \\
\text { mineralized }\end{array}$ \\
\hline $\begin{array}{l}14 \mathrm{~g} \text { aged detritus } \\
\text { per aquarium }\end{array}$ & 192 & 0.103 & 1.24 & 0.7 & 0.426 & 5.11 & 2.7 \\
\hline $\begin{array}{l}50 \mathrm{~g} \text { aged detritus } \\
\text { per aquarium }\end{array}$ & 685 & 0.604 & 7.25 & 1.0 & 4.311 & 51.7 & 7.6 \\
\hline $\begin{array}{l}50 \mathrm{~g} \text { fresh detritus } \\
\text { per aquarium }\end{array}$ & 729 & 3.575 & 42.9 & 5.9 & 10.157 & 121.9 & 16.7 \\
\hline $\begin{array}{l}\text { a Calculated from } \\
\text { weight of aged } \\
\text { Determined fror } \\
\text { values from the } \\
c \text { Calculated on th }\end{array}$ & $\begin{array}{l}\text { tal organic ca } \\
\text { tritus contain } \\
\text { cumulative } \mathrm{O} \\
\text { ntrol sedimer } \\
\text { basis that } 1 \mathrm{~m}\end{array}$ & $\begin{array}{l}\text { on analyses in } \\
77 \mathrm{mg} \mathrm{C} \\
\text { ptake or } \mathrm{CO}_{2} \\
\text { without } S p a r t i \\
\text { of } \mathrm{O}_{2} \text { consume }\end{array}$ & $\begin{array}{l}\text { dicating that } \\
\text { elease by sed } \\
\text { na } \\
\text { d or } \mathrm{CO}_{2} \text { prod }\end{array}$ & $\begin{array}{l}\text { g dry weigh } \\
\text { nent contair } \\
\text { aced is equi }\end{array}$ & $\begin{array}{l}\text { esh detritus co } \\
\text { Spartina minu } \\
\text { t to } 1 \mathrm{~mol} \text { of o }\end{array}$ & $\begin{array}{l}\text { ntains } 401 \mathrm{mg} \\
\text { the equivale } \\
\text { ganic carbon }\end{array}$ & $\begin{array}{l}\text { C and } 1 \mathrm{~g} \text { dry } \\
\text { t cumulative } \\
\text { nineralized }\end{array}$ \\
\hline
\end{tabular}


in the aquaria containing fresh or aged detritus was calculated from cumulative $\mathrm{O}_{2}$ uptake or $\mathrm{CO}_{2}$ release over the entire $30 \mathrm{~d}$ (Table 1); between 2.2 and 5.9 times more fresh detritus was metabolized than aged detritus.

The Eh of sediment containing fresh plant material (Fig. 2A) decreased rapidly with depth and reached anaerobic values $(-250 \mathrm{mV})$ at 1 to $2 \mathrm{~cm}$ sub-bottom, where the detritus appeared to be located (Fig. 2B). The Eh profiles of sediment with aged or no detritus departed from the initial profile during the experiment (Fig. 2C), but these changes were far less pronounced than the rapid development of an anaerobic Eh profile in sediment containing fresh detritus. Only in the sediment containing $50 \mathrm{~g}$ of aged detritus did the Eh profile reach negative values. The Eh of sediment containing $14 \mathrm{~g}$ of aged detritus remained close to control values.

The cumulative $\mathrm{O}_{2}$ uptake and $\mathrm{CO}_{2}$ release by sediment containing aged or no detritus appeared to fall into 2 distinct regions (Fig. 3), i.e. from 0 to $8 \mathrm{~d}$, where the slopes of the cumulative plots were relatively steep, and from 8 to $30 \mathrm{~d}$, where the slopes decreased. Slope breaks of the cumulative plots from sedinent containing fresh detritus (Fig. 3) were less welldefined and appeared to take place at 15 rather than $8 \mathrm{~d}$. The ratio of cumulative $\mathrm{CO}_{2}$ release to cumulative $\mathrm{O}_{2}$ uptake by all of the sediments was between 3.9 and 6.9 from 0 to $8 \mathrm{~d}$ (Fig. 4). These ratios tended to be greater than the ratios of between 2.0 and 4.0 which were calculated for 8 to $30 \mathrm{~d}$. During both time periods, the ratio of $\mathrm{CO}_{2}$ release to $\mathrm{O}_{2}$ uptake by sediment containing fresh detritus was consistently less than the ratios from the other sediments (Fig. 4).

The ${ }^{14} \mathrm{CO}_{2}$ release by the uninhibited core spiked with ${ }^{14} \mathrm{C}$-labelled hay reached a maximum at $5 \mathrm{~d}$ (Fig. 5A), which agreed with the data presented in Fig. 1. The addition of molybdate had a relatively small effect, causing a $5 \%$ reduction of the release rate at $5 \mathrm{~d}$. Azide had a large effect, decreasing the release rate by $88 \%$. DO ${ }^{14} \mathrm{C}$ release rates reached maximum values at 3 or $4 \mathrm{~d}$ and decreased rapidly to very low values by $5 \mathrm{~d}$. The cumulative ${ }^{14} \mathrm{CO}_{2}$ released from 0 to $8 \mathrm{~d}$ was 4.7 times greater than the $\mathrm{CO}_{2}$ released from 20 to $28 \mathrm{~d}$ (Fig. 6), and the effect of molybdate was distinctly different during these 2 periods. From 0 to $8 \mathrm{~d}$, molybdate reduced the $\mathrm{CO}_{2}$ released by $21 \%$, and
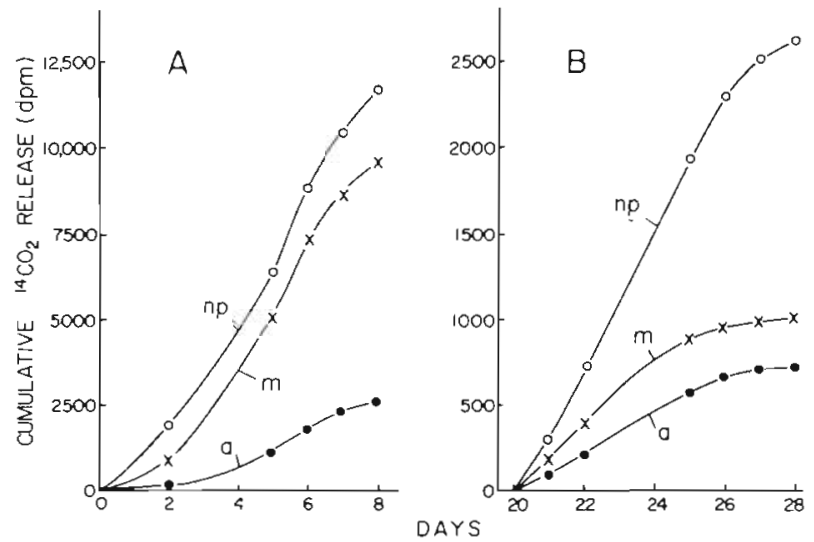

Fig. 6. (A) Cumulative release of ${ }^{14} \mathrm{CO}_{2}$ from 0 to $8 \mathrm{~d}_{\text {; }}$ (B) curnulative release from 20 to $28 \mathrm{~d}$ in cores not inhibited (np), molybdate inhibited (m), or azide inhibited (a)

azide caused a $77 \%$ reduction. From 20 to $28 \mathrm{~d}$, molybdate caused a far larger (62\%) reduction in the $\mathrm{CO}_{2}$ released, whereas azide had approximately the same effect, causing a $73 \%$ reduction. During both time periods, any increase of $\mathrm{DO}^{14} \mathrm{C}$ release caused by molybdate or azide was accompanied by an equivalent decrease in the release of $\mathrm{CO}_{2}$ (Table 2). A similar pattern was observed in the distribution of ${ }^{14} \mathrm{CO}_{2}$ and $\mathrm{DO}^{14} \mathrm{C}$ with depth in the sediment sampled at the end of the experiments (Fig. 7). Azide caused an increase in the amount of DOC and a decrease in the amount of $\mathrm{CO}_{2}$ remaining in the sediment. Molybdate had a more pronounced effect on DOC retention and the inhibition of $\mathrm{CO}_{2}$ production below $1.5 \mathrm{~cm}$, where anaerobic conditions were dominant. In addition, the amount of DOC retained in the sediment due to the action of the inhibitors (Fig. 7B) was approximately 5 times greater

Table 2. Effect of metabolic inhibitors on the release of ${ }^{14} \mathrm{CO}_{2}$ and $\mathrm{DO}^{14} \mathrm{C}$ from sediment containing fresh detritus spiked with ${ }^{14} \mathrm{C}$-labelled hay

\begin{tabular}{|c|c|c|c|c|c|c|c|c|c|}
\hline \multirow{3}{*}{ Inhibitor } & \multirow{3}{*}{$\begin{array}{c}{ }^{14} \mathrm{C} \text {-hay added } \\
\text { (dpm) }\end{array}$} & \multicolumn{4}{|c|}{0 to $8 \mathrm{~d}$} & \multicolumn{4}{|c|}{20 to $28 \mathrm{~d}$} \\
\hline & & \multicolumn{2}{|c|}{$\begin{array}{c}\mathrm{CO}_{2} \text { released } \\
\text { core } \mathrm{C}^{-1}\end{array}$} & \multicolumn{2}{|c|}{$\begin{array}{c}\text { DOC released } \\
\text { core } e^{-1}\end{array}$} & \multicolumn{2}{|c|}{$\begin{array}{c}\mathrm{CO}_{2} \text { released } \\
\text { core }^{-1}\end{array}$} & \multicolumn{2}{|c|}{$\begin{array}{c}\text { DOC released } \\
\text { core }^{-1}\end{array}$} \\
\hline & & $(\mathrm{dpm})$ & $(\%)^{\bullet}$ & $(\mathrm{dpm})$ & $(\%)^{\cdot}$ & $(\mathrm{dpm})$ & $(\%)^{\circ}$ & (dpm) & $(\%)^{\circ}$ \\
\hline None & $1.42 \times 10^{6}$ & 12,833 & 0.90 & 2,444 & 0.17 & 2,690 & 0.19 & 642 & 0.05 \\
\hline $20 \mathrm{mM}$ molybdate & $1.42 \times 10^{6}$ & 10,099 & 0.71 & 8,868 & 0.63 & 1,013 & 0.07 & 959 & 0.07 \\
\hline $20 \mathrm{mM}$ azide & $1.42 \times 10^{6}$ & 2,997 & 0.21 & 12,641 & 0.89 & 731 & 0.05 & 2,791 & 0.20 \\
\hline
\end{tabular}


than the $\mathrm{CO}_{2}$ retained (Fig. $7 \mathrm{~A}$ ). The $\mathrm{PO}^{14} \mathrm{C}$ remaining in the cores after $28 \mathrm{~d}$ (Fig. $7 \mathrm{C}$ ) all appeared to remain between 1.25 and $1.75 \mathrm{~cm}$ below the sediment surface. The discrepancy between the occurrence of $\mathrm{PO}^{14} \mathrm{C}$ peaks (which should have all been at $1.5 \mathrm{~cm}$ ) was probably related to the problem of injecting the slurry of hay and mud at exactly the same depth in each core.
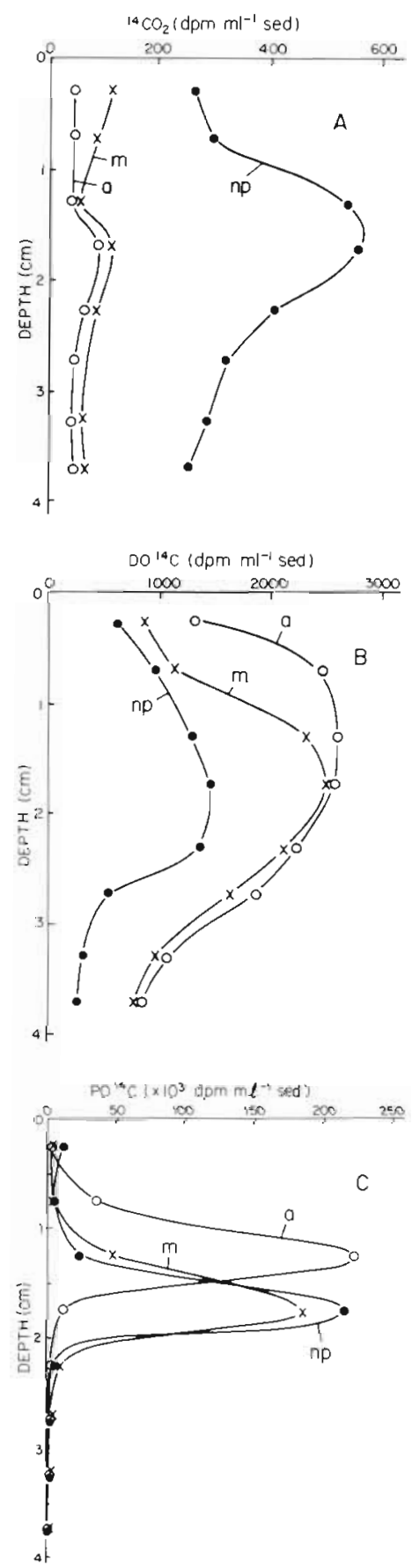

Fig. 7. (A) Distribution of ${ }^{14} \mathrm{CO}_{2}$; (B) distribution of $\mathrm{DO}^{14} \mathrm{C} ;(\mathrm{C})$ distribution of $\mathrm{PO}^{14} \mathrm{C}$ with depth in sediment containing fresh detritus after $28 \mathrm{~d}$ of decomposition

\section{DISCUSSION}

The results from sediment containing finely-ground Spartina kept at constant temperature in aquaria are not necessarily representative of salt marshes in the Bay of Fundy, where tides produce large fluctuations of temperature (Hargrave et al., 1983) and the detritus exists as large fragments (Gordon et al., 1984). Oxygen uptake rates in our aquaria (Fig. 1C) ranged from $0.4 \mathrm{mmol} \mathrm{m} \mathrm{m}^{-2} \mathrm{~h}^{-1}$ in the control sediment to a mean value of $2.5 \mathrm{mmol} \mathrm{m} \mathrm{m}^{-2} \mathrm{~h}^{-1}$ for the same sediment containing fresh detritus. These values are not out of place when compared to data from natural salt marshes. Oxygen uptake rates by sediments in the Bay of Fundy range from $0.6 \mathrm{mmol} \mathrm{m} \mathrm{m}^{-2} \mathrm{~h}^{-1}$ in natural, intertidal sediment (Hargrave et al., 1983) to a mean value of $1.9 \mathrm{mmol} \mathrm{m} \mathrm{m}^{-2} \mathrm{~h}^{-1}$ for sediment enriched with fresh Spartina detritus (Andersen and Hargrave, 1984). All of these values are close to or within the range of 0.6 to $8.3 \mathrm{mmol} \mathrm{m} \mathrm{m}^{-2} \mathrm{~h}^{-1}$ reported from more southerly marshes (Howarth and Hobbie, 1982). The mean carbon dioxide release rate by sediment that was not enriched with detritus $\left(2.3 \mathrm{mmol} \mathrm{m}^{-2} \mathrm{~h}^{-1}\right)$ was also similar to a mean value of $2.2 \mathrm{mmol} \mathrm{m} \mathrm{m}^{-2} \mathrm{~h}^{-1}$ reported by Andersen and Hargrave (1984) from the Bay of Fundy, and to values found by Teal and Kanwisher (1961), Pamatmat (1968), Granéli (1979) and Hargrave and Phillips (1981) in other sediments. The organic carbon turnover calculated from the uptake and release data (Table 1) is also in good agreement with previous work, indicating that our data are reasonably representative of a natural marsh.

High ratios of $\mathrm{CO}_{2}$ release to $\mathrm{O}_{2}$ uptake (from 2.0 to 6.9; Fig. 4) are in agreement with ratios ranging from 1.0 to 5.0 in the Bay of Fundy (Andersen and Hargrave, 1984), from 1.8 to 4.0 in sandy, subtidal sediments (Hargrave and Phillips, 1981), and from 0.8 to 9.0 in a number of lakes (Rich, 1979). These high ratios illustrate the importance of anaerobic metabolism in the decomposition of buried detritus. The rapid development of low redox potentials (Fig. 2A) at the depth of detritus burial (Fig. 2B) supports this observation, but chemoautotrophic $\mathrm{CO}_{2}$ fixation (Kepkay and Novitsky. 1980) must be taken into account as an added complication to this simplistic picture. Sulfur oxidizing chemoautotrophy may well have been a significant process in the sediment containing fresh detritus because mats of the filamentous bacterium, Beggiatoa, developed on the sediment surface during the last $5 \mathrm{~d}$ of the experiments. $\mathrm{CO}_{2}$ fixation in the dark would also explain the consistently lower ratios of $\mathrm{CO}_{2}$ release to $\mathrm{O}_{2}$ uptake by sediment with fresh detritus (Fig. 4).

The anaerobic production of $\mathrm{CO}_{2}$ via sulfate reduction became more dominant as time progressed (Fig. 6), eventually accounting for $76 \%$ of the $\mathrm{CO}_{2}$ 
produced from 20 to $28 \mathrm{~d}$, and also may have been associated with the decrease in cumulative $\mathrm{O}_{2}$ uptake and $\mathrm{CO}_{2}$ release observed at 8 or $15 \mathrm{~d}$ (Fig. 3). The relatively low DOC release rates and the eventual uptake of DOC by the sediment (Fig. 1A) could have been due to a small production rate. This seems unlikely, however, when the effects of metabolic inhibitors are considered. The inhibition of ${ }^{14} \mathrm{CO}_{2}$ production and its release from the sediment was always associated with an equivalent increase of $\mathrm{DO}^{14} \mathrm{C}$ release (Table 2 ). In addition, the maximum DOC and $\mathrm{DO}^{14} \mathrm{C}$ release rates occurred 1 to $2 \mathrm{~d}$ before the maximum $\mathrm{CO}_{2}$ and ${ }^{14} \mathrm{CO}_{2}$ release rates (Fig. 1 and 5), and decreased as $\mathrm{CO}_{2}$ release became dominant. This association of DOC production and its consumption to produce $\mathrm{CO}_{2}$ was also apparent within the sediment (Fig. 7), but approximately 5 times more DOC was retained due to the action of inhibitors. This enhanced retention of the DOC may have been related to $\mathrm{CO}_{2}$ diffusing out of the sediment more rapidly than the larger molecules of DOC.

Results from the labelled substrate experiments can only be used to estimate the effect of specific metabolic inhibitors on Spartina decomposition. The percentage of ${ }^{14} \mathrm{C}$-labelled hay released as $\mathrm{CO}_{2}$ into the water column over two $8 \mathrm{~d}$ periods was only $1.1 \%$ of the material injected into the sediment (Table 2). In contrast, the percentage of fresh Spartina released as $\mathrm{CO}_{2}$ over $30 \mathrm{~d}$ was 15.3 times higher or $16.7 \%$ of the material buried (Table 1). This may or may not mean that the hay was more refractory, but certainly indicates that data from its decomposition cannot be used to quantitatively predict the fate of buried Spartina detritus. However, by comparing the relative effect of metabolic inhibitors on the decomposition process, the results can be used to explain why so little DOC has been observed to escape from salt marsh sediments (Fig. 1A; Pomeroy et al., 1977; Andersen and Hargrave, 1984). Most of it is mineralized, initially by aerobes over the short term and then by sulfate-reducing anaerobes over the long term (Fig. 5 and 6). This consumption and mineralization of the DOC appears to keep pace with its production (Table 2), leaving only a small fraction to diffuse into the water column. The consumption of DOC by a predominantly anaerobic community may even outstrip production, resulting in a net uptake rather than release of DOC by the sediment (Fig. 1A). The data from azide-inhibited cores (Fig. 5 and 6), which indicate residual $\mathrm{CO}_{2}$ production despite the presence of azide, also suggest that a process other than respiration can produce $\mathrm{CO}_{2}$. When the anaerobic nature of the sediment and the relatively large DOC production are taken into account, it seems likely that the process is fermentation. A quantitative understanding of the types of fermentation producing the DOC for both aerobic and anaerobic respiration is now required for a better understanding of the fate of buried detritus.

\section{LITERATURE CITED}

Andersen, F. Ø., Hargrave, B. T. (1984). Effects of Spartina detritus enrichment on aerobic/anaerobic benthic metabolism in an intertidal sediment. Mar. Ecol. Prog. Ser. 16: $161-171$

Gershey, R. M., Mackinnon, M. D., Williams, P. J. le B., Moore, R. M. (1979). Comparison of three oxidation methods for the analysis of dissolved organic carbon in seawater. Mar. Chem. 7: 289-306

Good, R. E., Good, N. F., Frasco, B. R. (1982). A review of primary production and decomposition dynamics of the below ground marsh component. In: Kennedy, V. S. (ed.) Estuarine comparisons. Academic Press, London, p. 139-157

Gordon, D. C., Jr., Cranford, P. J., Desplanque, C. (1984). Observations on the ecological importance of salt marshes in the Cumberland Basin, a macrotidal estuary in the Bay of Fundy. Estuar. coast. Shelf Sci. (in press)

Granéli, W. (1979). A comparison of carbon dioxide production and oxygen uptake in sediment cores from four south Swedish lakes. Holarc. Ecol. 2: 51-57

Griffiths, R. P., Hayasaka, S. S., McNamara, T. M., Morita, R. Y. (1977). Comparison between two methods of assaying relative microbial activity in marine environments. Appl. environ. Microbiol. 34: 801-805

Hargrave, B. T. (1972). Oxidation-reduction potentials, oxygen concentration and oxygen uptake of profundal sediments in a eutrophic lake. Oikos 23: 167-177

Hargrave, B. T., Phillips, G. A. (1981). Annual in situ carbon dioxide and oxygen flux across a subtidal marine sediment. Estuar. coast. Shelf Sci. 12: 725-737

Hargrave, B. T., Prouse, N. J., Phillips, G. A., Neame, P. A. (1983). Primary production and respiration in pelagic and benthic communities at two intertidal sites in the upper Bay of Fundy. Can. J. Fish. aquat. Sci. 40 (Suppl. 1): 229-243

Howarth, R. W., Hobbie, J. E. (1982). The regulation of decomposition and heterotrophic microbial activity in salt marsh soils: a review. In: Kennedy, V. S. (ed.) Estuarine comparisons. Academic Press, London, p. 183-207

Kepkay, P. E., Novitsky, J A. (1980). Microbial control of organic carbon in marine sediments: Coupled chemoautotrophy and heterotrophy. Mar. Biol. 55: 261-266

MacKinnon, M. D., Walker, A. D. (1979). Comparison of carbon content of the sediments and their pore waters in salt marshes at Kingsport and Grand Pré, Minas Basin, Bay of Fundy, Nova Scotia. Proc. N.S. Inst. Sci. 29: 373-379

Mann, K. H. (1972). Macrophyte production and detritus food chains in coastal waters. Mem. Ist. Ital. Idrobiol. 29 (Suppl.): 353-383

Marinucci, A. C. (1982). Carbon and nitrogen fluxes during decomposition of Spartina alterniflora in a flow-through percolator. Biol. Bull. mar. biol. Lab., Woods Hole 162: $53-69$

Novitsky, J. A., Kepkay, P. E. (1981). Patterns of microbial heterotrophy through changing environments in a marine sediment. Mar. Ecol. Prog. Ser. 4: 1-7

Odum, E. P., de la Cruz, A. A. (1967). Particulate organic detritus in a Georgia salt marsh - estuarine ecosystem. In: Lauff, G. H. (ed.) Estuaries. Am. Ass. Adv. Sci., Washington, p. $383-388$ 
Oremland, R. S., Taylor, B. F. (1978). Sulfate reduction and methanogenesis in marine sediments. Geochim. cosmochim. Acta 42: 209-214

Pamatmat, M. M. (1968). Ecology and metabolism of a benthic community on an intertidal sand flat. Int. Revue ges. Hydrobiol. 53: 211-298

Patriquin, D. G. (1981). The general biology of salt marshes. In: Hatcher, A., Patriquin, D. G. (ed.) Salt marshes in Nova Scotia. Institute for Resource and Environmental Studies, Dalhousie University, p. 4-27

Pomeroy, L. R., Bancroft, K., Breed, J., Christian, R. R., Frankenberg, D., Hall, J. R., Mauer, L. G., Wiebe, W. J., Wiegert, R. F., Wetzel, R. L. (1977). Flux of organic matter through a salt marsh. In: Wiley, M. (ed.) Estuarine processes, VI. Academic Press, New York, p. 270-297

Rich, P. H. (1979). Differential $\mathrm{CO}_{2}$ and $\mathrm{O}_{2}$ benthic community metabolism in a soft water lake. J. Fish. Res. Bd Can. 36: $1377-1389$

Roberts, D. L. (1982). Distribution of organic carbon and nitrogen in various natural particle types of a fine intertidal sediment. M. Sc. thesis, Dalhousie University

Schwinghamer, P., Tan, F. C., Gordon, D. C., Jr. (1983). Stable carbon isotope studies on the Pecks Cove mudflat ecosys- tem in the Cumberland Basin, Bay of Fundy. Can. J. Fish. aquat. Sci. 40 (Suppl. 1): 262-272

Smith, D. L., Bird, C. J., Lynch, K. D., McLachlan, J. (1980). Angiosperm productivity in two salt marshes of Minas Basin. Proc. N.S. Inst. Sci. 30: 109-118

Sørensen, J., Christensen, D., Jørgensen, B. B. (1981). Volatile fatty acids and hydrogen as substrates for sulfate reducing bacteria in anaerobic marine sediment. Appl. environ. Microbiol. 42: 5-11

Stainton, M. P. (1973). A syringe gas stripping procedure for gas chromatographic determination of dissolved inorganic and organic carbon in fresh water and carbonates in sediments. J. Fish. Res. Bd Can. 30: 1441-1445

Stouthamer, A. H., van't Riet, J., Oltmann, L. F. (1980). Respiration with nitrate as an acceptor. In: Knowles, C. J. (ed.) Diversity of bacterial respiratory systems, Vol. II. CRC Press, Boca Raton, Florida, p. 19-48

Teal, J. M., Kanwisher, J. (1961). Gas exchange in a Georgia salt marsh. Limnol. Oceanogr. 6: 388-399

Thauer, R. K., Badziong, W. (1980). Respiration with sulfate as an electron acceptor. In: Knowles, C. J. (ed.) Diversity of bacterial respiratory systems, Vol. II. CRC Press, Boca Raton, Florida, p. 65-86 